\title{
MARKET COINTEGRATION AND RED CHILI PRICE BEHAVIOR BETWEEN WHOLESALERS AND TRADITIONAL MARKETS
}

\author{
Kapioru Charles, Bano Maria, Nendissa Doppy Roy* \\ Department of Agribusiness, Faculty of Agriculture, University of Nusa Cendana, Indonesia \\ ${ }^{*}$ E-mail: roynendissa@staf.undana.ac.id
}

\begin{abstract}
Chili is a very important food ingredient for a large part of the population in Asia including Indonesia, so it is sensitive to price changes. Research on market cointegration and red chili price behavior between wholesalers and traditional markets in NTT has not been found. This study uses the Johansen model cointegration approach and Granger causality with 96 time series price data for red chilies. This analysis measures the relationship between price changes in wholesalers and price changes in traditional markets. Using graphical methods and coefficient of variation (CV) to observe and measure price behavior patterns. This study contributes to the decision making to face the risk of price volatility. The results of the study found that changes in the price of red chili in traditional markets have an effect on prices in wholesalers. but it does not happen otherwise, meaning that there is no causality relationship. Wholesalers control the price of chili in traditional markets to the end consumers and the price variations in wholesalers are higher than in traditional markets. Price behavior in wholesalers and traditional markets exhibits the same pattern. Seasonal influence is not the main determinant of price fluctuations. It is suspected that the market infrastructure and the smoothness of the shifting chains are one of the determinants of price fluctuation. Improvements in infrastructure and market information are needed in order for market players to plan and make the right decisions.
\end{abstract}

\section{KEY WORDS}

Wholesalers, traditional markets, cointegration, price fluctuation, price behaviour.

Chili, like most people in Indonesia, is a staple food and is always present in cooking as a seasoning. Data from the Food and Agriculture Organization (FAO) released by Pusdatin (2019), Indonesia is the country with the largest harvest area for chili peppers in Southeast Asia (ASEAN) with a contribution of $92.91 \%$, while in the world Indonesia ranks second after China.

Some related research, namely Chilli production and adoption of chilli-based agribusiness in Indonesia (Mariyono \& Sumarno, 2015), Tree planting on deforested farmlands, Sewu Hills, Java, Indonesia: Impact of economic and institutional changes (Nibbering, 1999), Socio-economic factors affecting adoption of hybrid seeds and silvery plastic mulch for chili farming in Central Java (Kuntariningsih., \& Mariyono, 2013), Market integration of red chilli commodity markets in Indonesia (Jubaedah, 2013), The economic aspects of chilli production in Central Java (Bhattarai \& Mariyono, 2016), Supply Chain Design Of Chili Commodity To Improve The National Food Security By System Dynamics Simulation (Ridwan et al., 2017), Market integration and price formation of chili in Indonesia (Kustiari, 2017).

Chili has several types that are widely available in Indonesia, among which the most popular are red chilies, red curly chilies, bird's eye chilies, and green chilies. Red chilies are widely traded and become the main raw material for processed chilies whose products are widely exported. So that red chilies have a very big influence on the dynamics of the Indonesian economy, not only fluctuates but contributor to inflation, (Sativa, Harianto \& Suryana, 2017; Pusdatin 2019).

More than $47.4 \%$ of the red chili production centers are still concentrated on the island of Java in three provinces and the rest are outside the island of Java, while the need for chili spreads throughout Indonesia. Uneven production and consumption areas cause an 
imbalance between supply and demand. This imbalance causes the price to fluctuate frequently. The case that occurred in Jember, Indonesia, due to an imbalance in supply and demand, caused high fluctuations in chili prices (Eliyatiningsih Dana Mayasari, 2017). On the other hand, price fluctuations occur due to weak marketing infrastructure and the distance between production areas and consumers is very large, such as Indonesia which consists of 17 thousand islands. The disparity between regions is also one of the reasons for the weak flow of trade in goods and market information systems.

East Nusa Tenggara (NTT) Province is one of the regions that is not a center of red chili production, and is always deficient. The dependence on the supply of red chilies from the surplus areas is very large. Wholesalers play a very important role in the distribution of red chili trade to NTT. The main problem that is often faced by NTT in trade is the inefficient marketing system. The role of a marketing agency that has market power will easily adjust prices to the level of the traditional market or the consumer market. wholesalers are thought to have an important role in integrating prices at the lower market levels. In addition, the behavior and price fluctuations will follow any changes in the situation, both in season and the imbalance price policy of demand and supply of red chilies.

BPS data (2017) reported by Antara News 2017, that the production of red chili in NTT in the last 3 years has fluctuated and the trend has decreased by $19.77 \%$ from the previous year. The cause of the decline is due to the decreased harvest area and productivity so that NTT always has a shortage of red chili supplies. To meet the needs, it is always imported from outside the region through intermediary wholesalers to retail traders in traditional markets.

The gap between production, availability and demand for chili, triggered price fluctuations among wholesalers and in traditional markets. On the other hand, barriers to distribution and information asymmetry, due to weak marketing infrastructure in this area, have also triggered price movements and fluctuations. Whether or not there is a cointegration of chili prices between wholesalers and traditional markets is also a trigger for market inefficiency.

Studies on market cointegration are widely carried out, for example, Zhao, et al (2017); Lence, et al (2018); Xu, (2018); Kisswani, (2019); Rayhan, et al. (2019);Xu, (2019); Raghoo, and Surroop, (2020); and Butt, et al. (2020), Vollmer et al. (2020), Kassouri \& Altıntaş (2020), Chudy et al. (2020), Malkidis \& Fountas (2020), Raghoo \& Surroop (2020), Gjelsvik (2020), Zhang et al. (2020), Olayiwola \& Seeletse (2020), Chudy \& Hagler (2020), however, studies related to cointegration and price behavior between traditional markets and wholesalers have not been found much, especially in archipelagic areas and limited trading infrastructure. This study aims to answer the pattern of cointegration relationships and price causality and price behavior patterns among wholesalers and traditional markets. Information about market integration, according to $\mathrm{Li}$ (1997), is a means for decision makers to design profit maximization and improve social welfare.

\section{METHODS OF RESEARCH}

This study uses time series data, namely 96 weekly price data for red chilies for 20182019 in wholesalers and in traditional markets in East Nusa Tenggara (NTT) Province, Indonesia. The data source comes from the national strategic food price information center, the cooperation between Bank Indonesia and the Government of Indonesia to anticipate the national inflation rate. This study uses a cointegration analysis approach, graphic analysis and coefficient of variation. The process that is passed in the cointegration analysis is through the following stages:

Data stationarity is tested to avoid spurious regression, because time series data are often not stationary. Makridakis et al, (1999) stated that a series of data observations is called stationary if the process does not change with changing time. Data are not stationary if the mean, variance and covariance of the data are constant over time (Thomas, 1998). The data stationarity test is at a level or different by observing the ADF value, namely the variance is small, tends to approach the average value (Nendissa, et al 2018; Enders, 1995) 
The ADF test is used to observe whether there is a trend in chili price movements, and is formulated as follows:

$$
\Delta \mathrm{P}_{\mathrm{t}}=\mathrm{a}_{0}+\mathrm{\gamma}_{1} \mathrm{P}_{\mathrm{t}-1}+\beta_{\mathrm{I}} \sum_{\mathrm{I}=1}^{\mathrm{m}} \Delta \mathrm{P}_{\mathrm{t}-1}+\varepsilon_{\mathrm{it}}
$$

Where:

$\mathrm{P}_{\mathrm{t}}=$ Red chili prices in the period $t(\mathrm{RP} / \mathrm{Kg})$;

$\mathrm{P}_{\mathrm{t}-1}=$ The price of red chili in the previous $\mathrm{t}$ period $(\mathrm{RP} / \mathrm{Kg})$;

$\Delta \mathrm{P}_{\mathrm{t}}=\mathrm{P}_{\mathrm{t}}-\mathrm{P}_{\mathrm{t}-1}$

$\Delta \mathrm{P}_{\mathrm{t}-1}=\mathrm{P}_{\mathrm{t}-1}-\Delta \mathrm{P}_{(\mathrm{t}-1)-1}$

$\mathrm{m}=$ amount of lag;

$\mathrm{a}_{0}=$ intersep;

$\alpha, \beta, \gamma=$ Coefficient of Parameter;

$\varepsilon_{\mathrm{t}}=$ Error term;

Hypothesis:

- $\mathrm{H}_{0}: \mathrm{Y}=0$ time series data is not stationary;

- $\mathrm{H}_{1}: \mathrm{\gamma}<0$ stationary time series data.

Test rule:

- If the ADF statistical> ADF is critical, then Ho reject means that the time series data does not contain unit roots meaning that the data is not stationary;

- If the ADF statistic $\leq A D F$ is critical, then accept Ho, which means that the time series data contains unit roots, meaning that the data is stationary.

The optimal lag length is needed to see the effect of each variable on other variables in the VAR model. The lag value of a variable can affect other variables because it takes time for one variable to respond to the movements of other variables. Determination of the optimal lag length using Akaike Information Criteria (AIC).

Determination of the optimal lag length can take advantage of some information, namely by using Akaike Information Criterion (AIC) and Schwarz Criterion (SC), with the following formula:

$$
\begin{aligned}
& \ln (A I C)=\ln \frac{\sum \mathfrak{Q}_{i}^{2}}{n}+\frac{2 k}{n} \\
& \ln (S I C)=\ln \left(\frac{\sum \mathfrak{\Omega}_{i}^{2}}{n}\right)+\frac{k}{n} \ln (n)
\end{aligned}
$$

Where: $\hat{u}_{i}^{2}=$ sum of squared residuals; $\mathrm{k}=$ number of independent variables; $\mathrm{n}=$ number of observations.

The criterion that has the smallest AIC and SC values is the lag used.

Cointegration Testing gradation if the price variable under study is not integrated at the level. Cointegration test using Johansen's Cointegration Test, to find out whether or not integration occurs. The long-term equation can be formulated as follows:

$$
Y=C+\beta 1 X 1+\beta 2 X 2+\beta 3 X 3+\ldots+\beta n X n+\varepsilon
$$

Where: $Y=$ dependent variable; $C=$ independent variable; $\beta=$ constant; $X=$ independent variable coefficient; $\varepsilon=$ residual.

Cointegration is a combination of linear relationships of non-stationary variables, where all these variables must be integrated in the same order.

The Granger causality test is used to see the short-term causality of each variable that has root and is cointegrating (Sulistiana; 2017). Following are the steps for the EngleGranger test in brief (Rosadi, 2012) as follows. 
- Test for the unit root in the variable and (eg using the Augmented Dickey-Fuller or ADF test). These unit root orders must be the same and have a value of $d$. If the hypothesis of a unit root is rejected, the hypothesis of cointegration between variables will be rejected;

- Next, estimate the regression equation between Yt and Xt (or generally, between Yt and $(X t 1, X t 2, \ldots, X t k)$ and store the residuals from these regressions (just name this residual as et);

- Perform the unit root test on the residual et obtained in step 2. If the hypothesis of unit root is rejected, it is concluded that $\mathrm{Yt}$ and $\mathrm{Xt}$ are cointegrated (or in general $\mathrm{Yt}$ and $X t 1, X t 2, \ldots, X t k)$ are cointegrated). The unit root test for residuals, does not include a trend component in the test statistics.

Analysis of red chili price behavior patterns uses graphical analysis and measures variations in price movements using the Coefficient of Variation (CV), in percentage (\%).

Calculating the standard deviation (SD) needs to be done before measuring $\mathrm{CV}$; with the SD formula is:

$$
S D=\sqrt{\frac{\sum(X-x)^{2}}{n}}
$$

Where: $S D=$ Standard Deviation of price; $X=$ Change in price; $x=$ The average price change; $n=$ sum of average price.

Measuring the CV value of red chili prices at wholesalers and in traditional markets, with the formula:

$$
C V=\frac{\text { Standar Deviasi }(S D)}{\text { rata-rata harga }(x)} \times 100 \%
$$

The higher the CV percentage the greater the price fluctuation and vice versa. CV values between 5 - 9 percent, it is said that price fluctuations are relatively low to moderate; if the value is more than 9 percent, the fluctuation is high (Kemendag RI, 2015; Nendissa et al (2018).

\section{RESULTS AND DISCUSSION}

Distribution Pattern and Margin of Trade and Transportation (MPP) Red Chili. NTT is an archipelago whose inhabitants inhabit 43 of the 566 islands. As a large archipelago, transportation facilities, infrastructure and market information systems in distributing trade goods greatly determine the regional economy. The general distribution pattern of the red chili trade in Indonesia is dominated by views of middlemen with a relatively long number of trading channels, as shown in Figure 1.

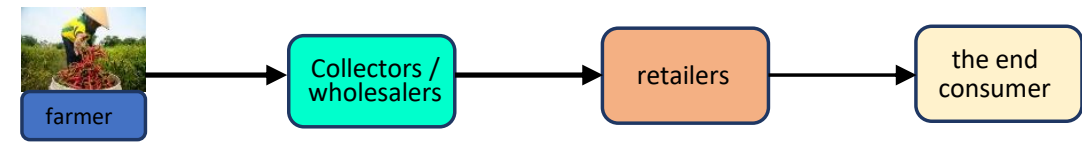

Figure 1 - Main distribution chain for red chili trade in Indonesia, 2019 (Ministry of Trade of the Republic of Indonesia, 2020)

However, the perpetrators of this distribution pattern can change, for example in 2017 the distribution pattern is different in 2018. In 2017 the distribution pattern is from farmers to wholesalers, retailers then to end consumers. The year 2018 changed from farmers to collectors, retailers and then final consumers (Kemendag RI, 2020). The distribution pattern of red chili trade affects the trade and transportation margin (MPP) of red chilies. The survey results found that in 2018 the national MPP of red chili was $43.09 \%$, decreased from 2017 which was $47.10 \%$. The increase in the price of red chili from the farmer level to the final 
consumer in NTT in 2017 reached $91.56 \%$, this is shown by the MPP value of red chili of $91.56 \%$, then dropped dramatically in 2018 .

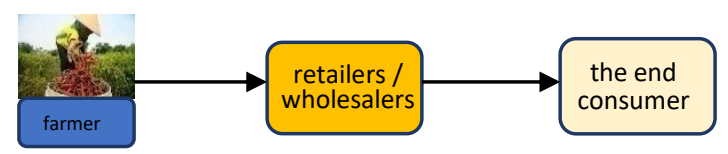

Figure 2 - Red chili trade distribution chain in NTT, 2019 (Kemendag RI, 2020)

The longer the distribution chain the greater the MPP value. BPS (2019) reports that the trade chain for several strategic commodities is getting shorter. The impact is that the selling price gap between producers and end consumers is getting closer together.

Testing the cointegration of red chili prices through several test stages, namely:

Data Stationarity Test. The stationarity test based on the Dickey-Fuller test shows that the data is not stationary at the zero degree or integration level data, I (0), so differencing data is carried out, namely reducing the data with the previous period data. Thus, through the first difference, the data on the difference or delta $(\Delta)$ is obtained. The Dickey - Fuller test procedure was then applied to test the stationarity of the differencing data. If the test results show that the time series data are not stationary, a second differencing is performed. The Dickey - Fuller test procedure was then applied to test the stationarity of the second differencing data.

The test results at the level are not stationary, so the unit root test is at the 1st Difference level in Table 1.

Table 1 - Test Data Stationarity

\begin{tabular}{|c|c|c|c|c|c|}
\hline \multirow[t]{3}{*}{ Variable } & \multicolumn{4}{|c|}{ Unit Root Test } & \multirow[t]{3}{*}{ Information } \\
\hline & \multicolumn{2}{|c|}{ Level } & \multicolumn{2}{|c|}{$1^{\text {st }}$ Difference } & \\
\hline & ADF & Prob. & ADF & Prob. & \\
\hline Traditional Market & -2.330040 & 0.1646 & -8.861477 & $0.0000^{* x}$ & Stationary \\
\hline Wholesalers & -2.332454 & 0.1639 & -5.137649 & 0.0000 & Stationary \\
\hline
\end{tabular}

Source: Secondary Data Processed, 2020.

The results of the stationarity test in table 1 show that based on the value of the ADF test, it can be concluded that the traditional market and wholesaler variables are stationary in the first difference condition. The existence of non-stationary variables at the level indicates a long-term relationship between variables (cointegration). So it is necessary to do a cointegration test to ensure the existence of a long-term relationship between the variables used.

Uji Cointegration. Based on the lag length above, we conducted a cointegration test to find out whether there would be a long-term balance, that is, there is a similarity in movement and stability of the relationship between the variables in this study or not. In this study, the cointegration test was carried out using the Johansen's Cointegration Test method. The following is a table of cointegration test results with the Johansen's Cointegration Test method.

Table 2 - Johansen cointegration test between traditional markets and wholesalers

\begin{tabular}{lcccc}
\hline $\begin{array}{l}\text { Hypothesized } \\
\text { No. of CE }(\mathrm{s})\end{array}$ & Eigenvalue & Trace Statistics & 0.05 Critical Value & Prob. ${ }^{* *}$ \\
\hline None ${ }^{*}$ & 0.070747 & 11,84668 & 15.49471 & 0.1644 \\
At most $1{ }^{*}$ & 0.041868 & 4.362460 & 3.841466 & 0.0367 \\
\hline
\end{tabular}

Source: Secondary Data Processed, 2020 Error level $(\alpha)=0.05$.

Based on Table 2, it can be seen that the trace statistic value is greater than the critical value with a significance level of 5 percent. So it can be said that there is an integration of 
red chili prices in the long term between traditional markets and wholesalers. Change in price of chili ontraditional markets and wholesalers there is a relationship in the long term, but in the short term it is unlikely to happen.

Granger Causality Test. The causality test is conducted to determine whether an endogenous variable can be treated as an exogenous variable using the Granger's Causality method. Granger's Causality is used to test the causality relationship between two variables. The predictive power from the previous information can indicate a causal relationship between one variable and another over a long period of time.

Table 3 - Granger Causability Test, Reciprocal Relations in both Markets

\begin{tabular}{llll}
\hline Null Hypothesis: & Obs. & F-Statistic & Prob. \\
\hline wholesalers does not Granger Cause Traditional Market & 100 & 1.30184 & 0.2704 \\
\hline Traditional Market does not Granger Cause wholesalers & & 15.0996 & $1 . \mathrm{E}-10$ \\
\hline
\end{tabular}

Source: Secondary Data Processed, 2020 Error rate $(\alpha)=0.05 \%$.

The results of the Granger causality test, which are presented in Table 3, show that changes in the price of red chilies in wholesalers will encourage changes in chili prices in traditional markets. Meanwhile, traditional market prices do not affect prices in wholesalers there is only a one-way relationship, there is no short-term causality. This shows that the controllers of chili prices are on the one hand, namely wholesalers because they have market power. The presumption of market information asymmetry is very strong because wholesalers have more control over information related to commodity trading than retailers in traditional markets. Retailers in traditional markets act only as price takers, while wholesalers act as price makers. On the other hand, the limited means of transportation and infrastructure in the study area because it consists of many islands provides support for this situation.

Analysis of Red Chili Price Behavior. Chili is the main food material needed daily by the Indonesian people, so it is very sensitive to price changes if supply is disrupted. The behavior of red chili prices shown in Figure 3 shows a very volatile movement and does not show a consistent and highly volatile pattern. The behavior of weekly red chili prices in January 2018 - December 2019 in wholesalers and traditional markets has a unidirectional movement pattern. Price movements in traditional markets are quite high and more volatile than prices at wholesalers. Price behavior in traditional markets is driven by price behavior that occurs in wholesalers. Price movements of red chilies that occur at wholesalers, so prices in traditional markets tend to follow them.

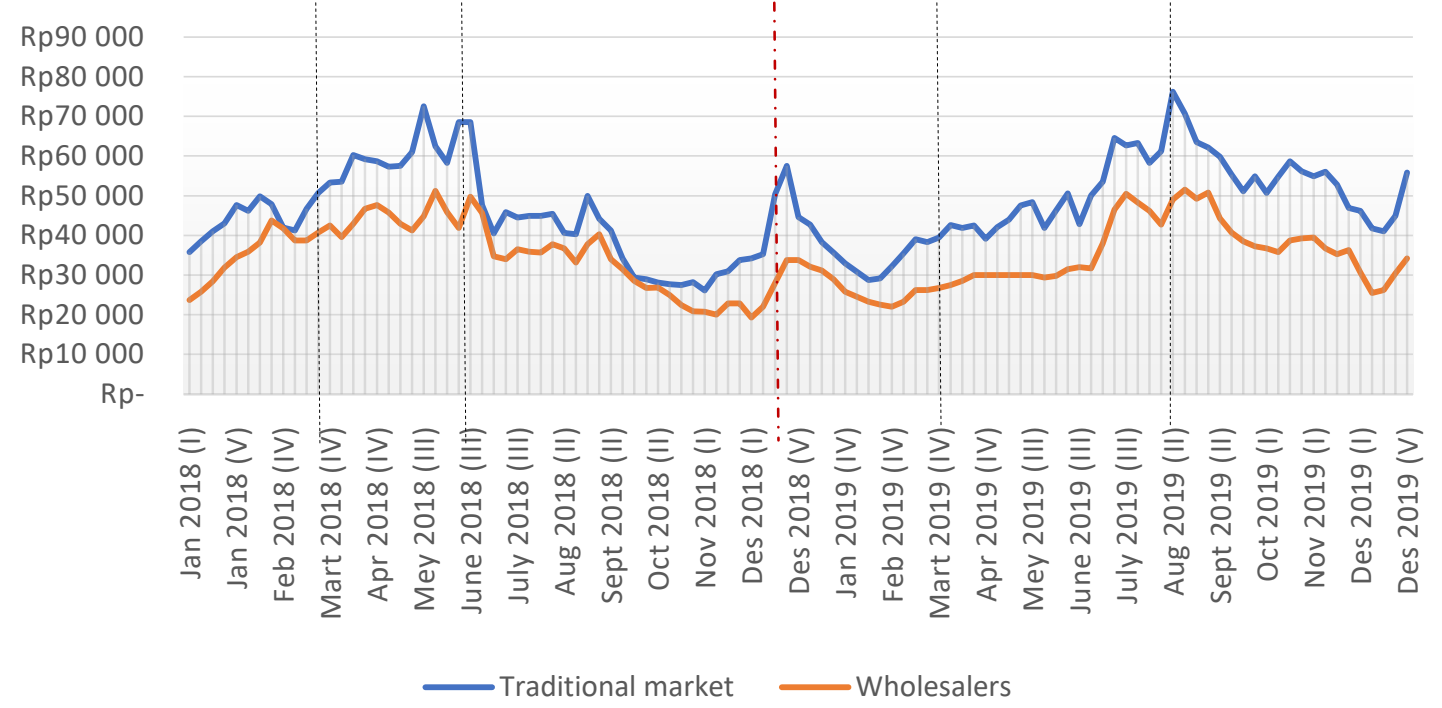

Figure 3 - Prices of red chili weekly price behavior in NTT, 2018-2019 (processed data) 
The lowest red chili price movement occurred around October 2018, in the following month it moved up to its highest point in May 2018, entering December 2018 again, it fell to its lowest point. In the following seasons, the highest prices occurred in August and December 2019. The highest price movement was probably because the supply was reduced, it did not last long, it will fall back when there are new supplies. Study resultsSabu, et al. (2019), found that the cycle and behavior of the lowest price period lasted longer than the boom period of black pepper prices. The movement of the price of agricultural commodities specifically maize in Iran, has its own price movement cycle (Fakari, et al, 2013). Study conducted Sabu, et al. 2019). The behavior of black pepper prices in India and internationally found that throughout the period the monthly price experienced high fluctuations apart from the season but also due to trade pre-liberalization. Cause the fluctuation of chili production, apart from the season, is also because production centers are concentrated in certain regions or islands (Supriyadi and Sejati, 2018). Meanwhile, chili consumers are scattered throughout Indonesia.

Compared to the pattern of price movements that occurred in Indonesia shown in Figure 4, in early 2017 it experienced a sharp decline until September 2017. Entering 20182019 the price of red chili still fluctuated, but not as extreme as 2017.

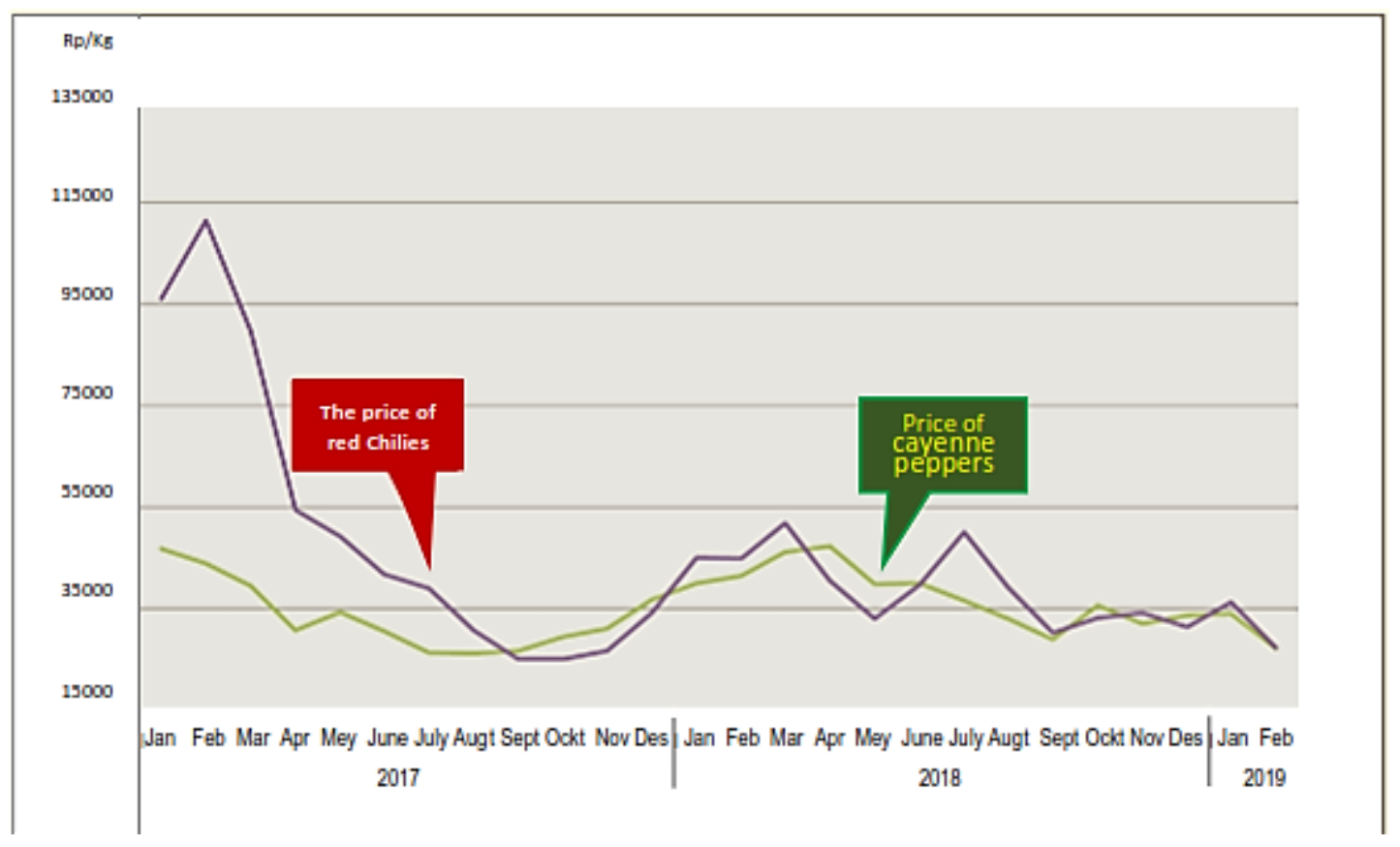

Figure 4 - The trend of red chili and curly chili price movements in Indonesia 2017-February 2019, (BPS 2019, which was adopted from the Kemendag RI, 2020)

Observing the weekly price movements in Figure 5, entering January-May 2020, entering the pre-pandemic Covic-19 situation, the price of chilies crept up to its highest point in March 2020. At the time of the pre-pandemic Covid-19 and began to apply social restrictions and working from home, there is panic buying, especially food. This prompted food prices to be pushed up for a while then continued to decline (figure 4). The price decline occurred due to a decline in people's purchasing power and disrupted distribution due to transportation restrictions.

Table 5, the CV value obtained at the price of chili in traditional markets and wholesalers for 2018 - 2019 ranges from $22.67 \%-24.67 \%$, it can be said that the level of fluctuation in chili prices during the period of January 2018 - December 2019 in NTT is said to fluctuate highly well in wholesalers and in traditional markets. Price movements in wholesalers are higher than traditional markets as indicated by the value of $\mathrm{CV}$. Wholesaler CV is $24.03 \%$ and CV in traditional market is $22.67 \%$. Price variations that occur in traditional 
markets last longer than those that occur at wholesalers. Wholesalers respond more quickly to price increases than red chili prices.

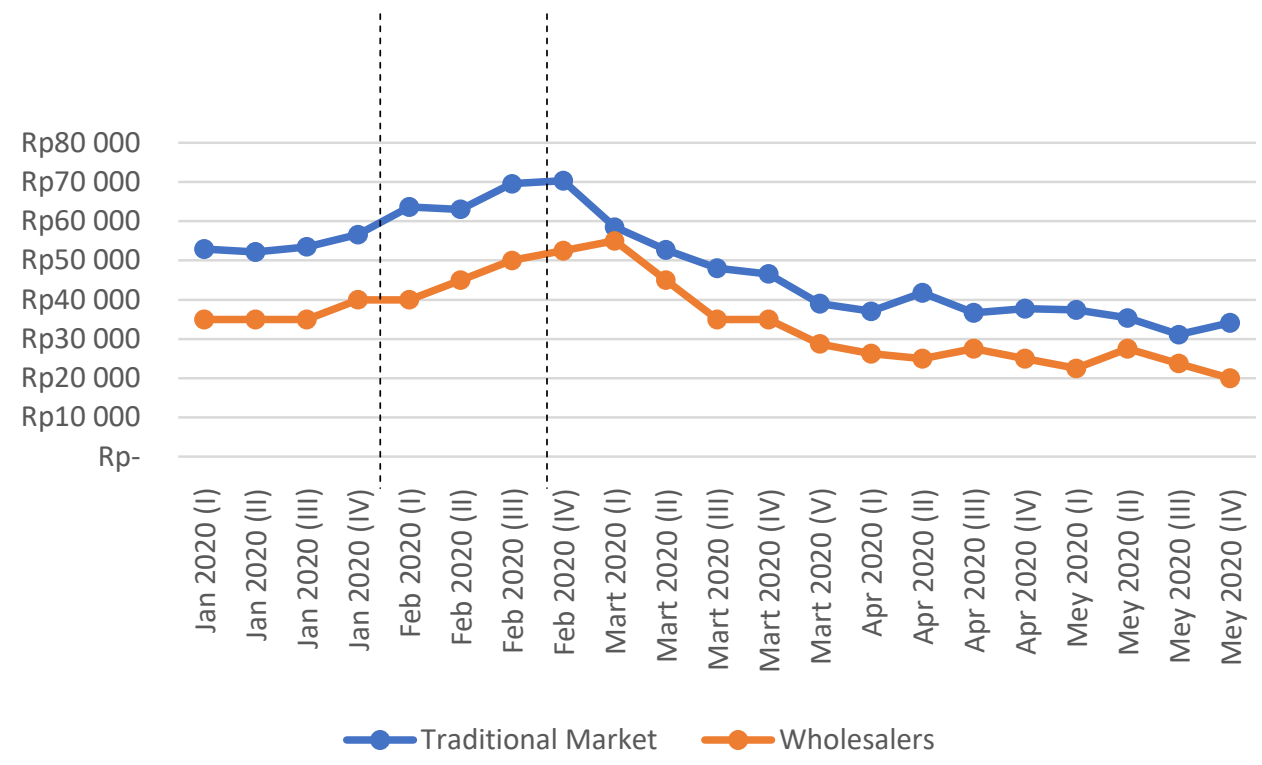

Figure 5 - The behavior of red chili prices during the pre-pandemic covid-19 January-May 2020

The behavior of red chili prices in traditional markets and in wholesalers is dynamic, and highly volatile. This is indicated by the relatively large number of CVs occurring in wholesaler markets compared to traditional markets.

Table 5 - Analysis of weekly price variations of red chili (CV), 2018-2019

\begin{tabular}{lll}
\hline \multirow{2}{*}{ Year } & Coefficient of Variation (\%) & \\
\cline { 2 - 3 } & Traditional Market & Wholesalers (wholesalers) \\
\hline 2018 & 23.76 & 24.67 \\
2019 & 22.67 & 24.03 \\
\hline
\end{tabular}

Source: The results of time series data analysis of weekly red chili prices for 2018-2029, (processed).

Based on these conditions, market players, namely wholesalers, retailers in traditional markets and end consumers, need to obtain real-time price information in order to make efficient decisions. Market information disclosure and improvement of marketing infrastructure are urgently needed by market players.

\section{CONCLUSION}

The price of red chili in wholesalers and in traditional markets is co-integration in the long term, but not in the short term. Price changes in traditional markets follow price changes in wholesalers but it does not happen the other way around. There is only a one-way relationship, so there is no causality relationship. Price makers have market power to push changes in chili prices in traditional markets, but traders in traditional markets (price takers) cannot adjust prices. The price behavior of red chilies in traditional markets and wholesalers shows a unidirectional and highly volatile movement pattern. The number of price fluctuations that occur in wholesalers is higher than traditional markets because the price is determined by wholesalers. Transportation and marketing infrastructure are thought to be obstacles to trade distribution and create price fluctuations. All market participants need to have sufficient price information to create an efficient market system. The role of government and related parties is important in providing price information and improving market infrastructure. 


\section{REFERENCES}

1. AntaraNews, (2017). Tingkat Produksi Cabai di NTT Fluktuatif; Senin, 16 Januari 2017 https://kupang.antaranews.com/berita/1508/tingkat-produksi-cabai-di-ntt-fluktuatif.

2. Bhattarai, M., \& Mariyono, J. (2016). The economic aspects of chilli production in Central Java. Economic Journal of Emerging Markets, 8(2), 85-97.

3. BPS NTT, (2018). Statistik Tanaman Sayuran and Buah buahan Nusa Tenggara Timur. ISN-2407-8387. Kupang

4. BPS RI .(2020). Pola Distribus Perdagangan Komoditi Strategis, Badan Pusat Statistik RI, Berita Resmi, Jakarta. Indonesia.

5. Butt, S., Ramakrishnan, S., Loganathan, N., \& Chohan, M. A. (2020). Evaluating the exchange rate and commodity price nexus in Malaysia: evidence from the threshold cointegration approach. Financial Innovation, 6, 1-19.

6. Chudy, R. P., \& Hagler, R. W. (2020). Dynamics of global roundwood pricesCointegration analysis. Forest Policy and Economics, 115, 102155.

7. Fakari, B., Farsi, M. M., \& Kojouri, M. (2013). Determining Fluctuations and Cycles of Corn Price in Iran. Agricultural Economics/ Zemedelska Ekonomika, 59(8).

8. Gjelsvik, M., Nymoen, R., \& Sparrman, V. (2020). Cointegration and Structure in Norwegian Wage-Price Dynamics. Econometrics, 8(3), 29.

9. Jubaedah, N. S. (2013). Market integration of red chilli commodity markets in Indonesia. International Institute of Social Studies,[Research Paper] Economic of Development. the Hague, the Netherlands.

10. Kassouri, Y., \& Altıntaş, H. (2020). Threshold cointegration, nonlinearity, and frequency domain causality relationship between stock price and Turkish Lira. Research in International Business and Finance, 52, 101097.

11. Kemendag RI. (2015). Laporan Analisis Outlook Pangan 2015-2019, Kementerian Perdagangan RI. Jakarta.

12. Kisswani, K. M. (2019). Asymmetric gasoline-oil price nexus: recent evidence from nonlinear cointegration investigation. Applied Economics Letters, 26(21), 1802-1806.

13. Kuntariningsih, A. P. R. I., \& Mariyono, J. O. K. O. (2013). Socio-economic factors affecting adoption of hybrid seeds and silvery plastic mulch for chili farming in Central Java. SEPA Jurnal Sosial Ekonomi Pertanian and Agribinis, 9(2), 297-308.

14. Kustiari, R. (2017). Market integration and price formation of chili in Indonesia. International Journal of Sciences: Basic and Applied Research, 36(3), 301-319.

15. Lence, S. H., Moschini, G., \& Santeramo, F. G. (2018). Threshold cointegration and spatial price transmission when expectations matter. Agricultural Economics, 49(1), 25-39.

16. Li, J. R. (1997). Price and Trade Relations and Market Integration in Pacific Pork Markets. Dissertation; Utah State University, Utah.

17. Makridakis, S,. Wheelwright, S.C,. and McGee, V.E. (1999). Metode and Aplikasi Peramalan. Jilid I. Edisi 2. Jakarta: Erlangga.

18. Malkidis, S., \& Fountas, S. (2020). Liquid fuel price adjustment in Greece: a two-stage, threshold cointegration approach. The Journal of Economic Asymmetries, 22, e00171.

19. Mariyono, J., \& Sumarno, S. (2015). Chilli production and adoption of chilli-based agribusiness in Indonesia. Journal of Agribusiness in Developing and Emerging Economies.

20. Nibbering, J. W. (1999). Tree planting on deforested farmlands, Sewu Hills, Java, Indonesia: Impact of economic and institutional changes. Agroforestry Systems, 46(1), 65-82.

21. Olayiwola, M. F., \& Seeletse, S. M. (2020). South African Petrol Price and Consumption Cointegration Analysis. Journal of Engineering and Applied Sciences, 15(6), 1579-1588.

22. Pusdatin (2019). Outlook Cabai, Pusat Data and Informasi Pertanian, Kementerian Pertanian RI.

23. Pusdatin, (2017). Outlook Tanaman Pangan and Horti Kultura, Sekretaris Jenderal Kementrian Pertanian RI. Pusat Data and Sistem Informasi Pertanian. 
24. Raghoo, P., \& Surroop, D. (2020). Price and income elasticities of oil demand in Mauritius: An empirical analysis using cointegration method. Energy Policy, 140, 111400.

25. Rayhan, S. J., Islam, M. J., Kazal, M. H., \& Kamruzzaman, M. (2019). Market Integration and Seasonal Price Variation of High-Value Vegetable Crops in Chittagong Hill Districts of Bangladesh. International Journal, 6(3), 150-165.

26. Ridwan, A., Ekawati, R., \& Nafiah, M. R. (2017). Supply Chain Design Of Chili Commodity To Improve The National Food Security By System Dynamics Simulation. In Proceeding the 1st International Conference on Food Security Innovation (Vol. 142, p. 160).

27. Roman, M. (2020). Spatial Integration of the Milk Market in Poland. Sustainability, 12(4), 1471.

28. Sabu, S. S., Kuruvila, A., \& Manojkumar, K. (2019). Price behaviour of black pepper in Indian and international markets: a comparative analysis. Journal of Spices and Aromatic Crops, 27-33.

29. Sativa, M., Harianto, H., \& Suryana, A. (2017). Impact of red chilli reference price policy in Indonesia. International Journal of Agriculture System, 5(2), 120-139.

30. Sawitania, C. D. U. S., \& Anindita, R. (2016). Analisis Integrasi Pasar Vertikal Cabai Merah Besar (Capsicum annuum L.) Di Jawa Timur. Agricultural Socio-Economics Journal, 13(2), 126.

31. Supriyadi, H., \& Sejati, W.K. (2018). Perdagangan Antarpulau Komoditas Cabai di Indonesia: Dinamika Produksi and Stabilitas Harga. Analisis akaebijakan Pertanian, 16(2):111-129.

32. Thomas, R. L., (1998). Model Econometrics: An Introduction. England: Eddison-Wesley. Harlow.

33. Vollmer, T., Herwartz, H., \& von Cramon-Taubadel, S. (2020). Measuring price discovery in the European wheat market using the partial cointegration approach. European Review of Agricultural Economics, 47(3), 1173-1200.

34. Xu, X. (2018). Cointegration and price discovery in US corn cash and futures markets. Empirical Economics, 55(4), 1889-1923.

35. Xu, X. (2019). Price dynamics in corn cash and futures markets: cointegration, causality, and forecasting through a rolling window approach. Financial Markets and Portfolio Management, 33(2), 155-181.

36. Zhang, D., Li, Q., Mugera, A. W., \& Ling, L. (2020). A hybrid model considering cointegration for interval-valued pork price forecasting in China. Journal of Forecasting.

37. Zhao, X., Zou, Y., Yin, J., \& Fan, X. (2017). Cointegration relationship between carbon price and its factors: evidence from structural breaks analysis. Energy Procedia, 142, 2503-2510. 